\title{
KERAGAMAN DAN KORELASI KANDUNGAN ALBUMIN DENGAN KARAKTER PERTUMBUHAN PADA TIGA POPULASI IKAN GABUS (Chana striata)
}

\author{
Ikhsan Khasani" dan Dessy Nurul Astuti \\ Balai Riset Pemuliaan Ikan \\ Jl. Raya Sukamandi No. 2, Subang 41256, Jawa Barat
}

(Naskah diterima: 19 September 2019; Revisi final: 13 Januari 2020; Disetujui publikasi: 13 Januari 2020)

\begin{abstract}
ABSTRAK
Albumin ikan gabus merupakan bahan farmasi bernilai tinggi, banyak dimanfaatkan untuk mengobati pasien pascaoperasi dan luka bakar. Penelitian ini bertujuan untuk menganalisis keragaman dan korelasi kandungan albumin terhadap karakter pertumbuhan pada tiga populasi ikan gabus (Chana striata) dari Sumatera (SM), Jawa (JW) dan Kalimantan (KL). Tahap awal dari penelitian ini adalah pemeliharaan larvabenih, karakterisasi dan analisis kandungan albumin ikan gabus dari tiga populasi. Kandungan albumin pada sampel daging (20 ekor ikan per populasi) dianalisis menggunakan reagen bromocresol green dan diukur dengan spektrofotometer pada $578 \mathrm{~nm}$. Benih ikan gabus dari populasi SM, JW, dan KL dengan ukuran panjang total $28,9 \pm 5,7 \mathrm{~mm}$ dan bobot badan $0,27 \pm 0,09 \mathrm{~g}$ dari 12 famili, terdiri dari 4 famili untuk setiap populasi dipelihara secara acak dalam 12 buah kolam beton ukuran $25 \mathrm{~m}^{2}$ selama 75 hari. Kandungan albumin rata-rata ketiga populasi tidak berbeda nyata ( $P>0,05)$, yaitu $2,6 \pm 0,4 \mathrm{~g} \mathrm{dL}^{-1}(\mathrm{KL}), 2,4$ $\pm 0,3 \mathrm{~g} \mathrm{dL}^{-1}(\mathrm{SM})$ dan $2,2 \pm 0,4 \mathrm{~g} \mathrm{dL}^{-1}(\mathrm{JV})$; dengan koefisien keragaman sebesar $12,60 \%(\mathrm{SM}), 18,13 \%(\mathrm{~T})$ dan $17,0 \%(\mathrm{KL})$. Nilai korelasi antara panjang total, panjang standar, dan bobot badan dengan kandungan albumin tergolong rendah hingga sedang, yaitu secara berurutan sebesar $-0,05 ;-0,03$ dan $-0,43$ (SM), 0,$42 ; 0,475$ dan $0,34(\mathrm{JW})$ dan $-0,28 ;-0,35$ dan $-0,275$ (KL). Hasil analisis tersebut menunjukkan bahwa keragaman kandungan albumin tidak berbeda antar populasi, sehingga pendekatan seleksi kurang efektif. Nilai korelasi antara karakter pertumbuhan terhadap kandungan albumin pada ikan gabus tergolong rendah.
\end{abstract}

KATA KUNCI: albumin; genetik; keragaman; korelasi; pertumbuhan

ABSTRACT: Variance and correlation of albumin content to growth character of three populations of snakehead fish (Chana striata). By: Ikhsan Khasani and Dessy Nurul Astuti

The snakehead fish (SHF) albumin is a highly valued pharmaceutical material widely used to treat postsurgery wounds and skin burns. This study's purpose was to analyze the coefficient of variance and correlation of albumin trait to growth characters of three SHF populations: Sumatera (SM ), Java (JV) and Kalimantan (KL). The first step of this study consisted of larval and seed rearing of three SHF populations followed up by characterization and analysis of their albumin content. The albumin contents of the SHF meat (20 fish for each population) were analyzed using bromocresol green reagent and measured using a spectrophotometer at $578 \mathrm{~nm}$. The SHF seeds $(28.9 \pm 5.7 \mathrm{~mm}$ of total length and $0.27 \pm 0.09 \mathrm{~g}$ of body weight) from 12 families consisted of four families for each population were reared in 12 concrete ponds measuring $25 \mathrm{~m}^{2}$ for 75 days. The averages of albumin content of the three populations were $2.6 \pm$ $0.4 \mathrm{~g} \mathrm{dL}^{-1}(\mathrm{KL}) 2.4 \pm 0.3 \mathrm{~g} \mathrm{dL}^{-1}(\mathrm{SM})$ and $2.2 \pm 0.4 \mathrm{~g} \mathrm{dL}^{-1}(\mathrm{JV})$ and considered not significantly different $(\mathrm{P}>0.05)$ with coefficients of variance of $12.60 \%(\mathrm{SM}), 18.13 \%(\mathrm{VV})$ and $17.0 \%(\mathrm{KL})$. The correlation values of total length (TL), standard length (SL) and body weight (BW) with albumin content of the SHF were $-0.05,-0.03$, and $-0.43(\mathrm{SM}) ; 0.42$, 0.475 , and $0.34(\mathrm{JV})$; and $-0.28,-0.35$, dan -0.275 (KL) and classified as low to moderate. The results suggested that the variances of albumin content among the populations were not significantly different and the individual selection method was not effective.

KEYWORDS: albumin; correlation; genetic; variance; growth

\footnotetext{
\# Korespondensi: Balai Riset Pemuliaan Ikan.

Jl. Raya Sukamandi No. 2, Subang 41256, Jawa Barat, Indonesia

Tel. + 62260520500

E-mail: ikhsankhasani@gmail.com
} 


\section{PENDAHULUAN}

Ikan gabus (Channa striata) telah menjadi sumber nutrisi penting bagi masyarakat pembudidaya ikan daerah pedalaman di sejumlah negara tropis dan subtropis, termasuk Indonesia (Mustafa et al., 2012; Gustiano et al., 2019). Ikan gabus merupakan sumber protein yang bermanfaat, disamping kandungan lemak, vitamin $A$, asam arakidonat (AA), asam docosahexaenoic (DHA) dan albumin (Suwandi et al., 2014; Rahman et al., 2018). Ikan adaptif dengan bentuk kepala menyerupai ular (snakehead) tersebut telah dikenal sebagai sumber obat bagi masyarakat di wilayah Asia Selatan, digunakan untuk mengobati luka, mengurangi rasa sakit, meningkatkan energi, antiinflamasi, agregasi trombosit, serta sifat antimikroba dan anti jamur yang ringan. Nutraseutik ikan gabus bernilai sangat tinggi, mengandung senyawa bioaktif yang berfungsi dalam uji klinis, terapi dan suplemen nutrisi (Siswanto et al. 2016; Rahman et al. 2018). Oleh karena itu, ikan gabus memiliki potensi tinggi untuk digunakan sebagai sumber obat-obatan dan nutrisi yang dapat diterima untuk pengo batan penyakit serius serta untuk perbaikan kesehatan tubuh manusia secara lebih luas (Courtenay \& Williams 2004). Oleh karena itu, permintaan akan ikan gabus di Indonesia dan pasar Asia selalu mengalami peningkatan, karena berperan sebagai immunostimulan, mempercepat penyembuhan luka, lebih khusus bagi pasien pasca operasi sesar (Mustafa et al., 2012; Dwijayanti et al., 2016; Rahman et al., 2018 ).

Berkaitan dengan fungsi ikan gabus dalam pengobatan, albumin diyakini sebagai protein fungsional utama pada spesies tersebut. Serum albumin pada ikan memainkan peran penting untuk transportasi produk metabolisme seperti asam lemak, hormon, dan bilirubin (Andreeva, 2011; Baker, 2002; Kovyrshina \& Rudneva, 2012), mengatur tekanan osmotik; dan memainkan peran dalam osmoregulasi (Zhang et al., 2005).

Kandungan albumin ikan gabus dari sumber populasi berbeda memiliki kecenderungan berbeda pula. Kandungan albumin ikan gabus yang dikoleksi dari perairan umum lebih tinggi dibandingkan ikan gabus hasil budidaya (Chasanah et al., 2015). Dinyatakan pula bahwa ikan gabus asal Jawa Barat memiliki kandungan albumin lebih tinggi dibandingkan ikan gabus asal Jawa Timur dan Jawa Tengah (Susilowati et al., 2015). Habitat juga berpengaruh terhadap kandungan albumin ikan gabus. Fuadi et al., (2017) menyatakan bahwa ikan gabus yang dikoleksi dari perairan payau memiliki kandungan albumin lebih tinggi dibandingkan ikan gabus dari perairan tawar. Perbedaan kandungan albumin antaraikan gabus yang dikoleksi dari perairan tawar dan perairan payau berkaitan dengan peran albumin dalam mekanisme adaptasi terhadap perubahan lingkungan. Dinyatakan oleh Andreeva (2010) bahwa albumin pada ikan berperan dalam mekanisme adaptasi terhadap sal initas dan kadarnya meningkat seiring peningkatan salinitas lingkungan. Selain dipengaruhi oleh faktor lingkungan, kandungan albumin juga dipengaruhi oleh ukuran ikan. Dinyatakan oleh Gam et al. (2006) dan Alfarisy et al., (2013), bahwa ikan gabus dengan ukuran lebih kecil memiliki kadar albumin lebih tinggi dibandingkan ikan gabus dengan ukuran lebih besar. Namun demikian, pendapat berbeda dinyatakan oleh Hariati et al. (2019), yang menyatakan bahwa ikan gabus dengan ukuran lebih besar memiliki kandungan protein dan albumin lebih tinggi dibandingkan ikan gabus dengan ukuran lebih kecil.

Adanya perbedaan atau variasi kandungan albumin antar populasi, antar habitat, dan antar ukuran ikan gabus mengindikasikan adanya peluang untuk dilakukan seleksi individu-individu atau populasi ikan gabus yang memiliki kandungan albumin lebih tinggi. Seleksi pada karakter kualitas daging, seperti kadar lemak, kandungan karotenoid, warna daging telah dilakukan dan memberikan keberhasilan pada sejumlah komoditas ikan budidaya (Gjedrem 2012; Gjedrem 2017).

Salah satu faktor penting penentu keberhasilan seleksi adalah variasi genetik pada karakter yang dikehendaki (Gjedrem 1983) dan korelasi genetik dengan sifat relevan lainnya yang termasuk dalam tujuan pemuliaan (Falconer \& Mackay, 1996). Variasi genetik yang tinggi terkait karakter yang dikehendaki merupakan modal penting untuk mencapai keberhasilan program seleksi (Gjedrem \& Baranski, 2009; Gjedrem et al., 2012; Rodriguez et al., 2018).

Pengukuran kadar albumin daging ikan gabus pada tahapan seleksi merupakan metode yang cukup mahal dan harus mematikan hewan uji, sehingga penggunaan karakter pertumbuhan sebagai penduga kandungan albumin dapat menjadi alternatif untuk memilih ikan gabus dengan kandungan albumin lebih tinggi. Penelitian ini bertujuan untuk mengetahui keragaman kandungan albumin dan korelasi kandungan albumin dengan karakter pertumbuhan pada ikan gabus dari tiga sumber populasi.

\section{BAHAN DAN METODE}

Penelitian utama dilakukan pada Mei - Desember 2018, di Balai Riset Pemuliaan Ikan, Subang, Jawa Barat. Kandungan albumin dianalisis di Laboratorium Pengawetan dan Pengolahan Produk Akuatik, Institut Pertanian Bogor, Jawa Barat. Calon induk ikan gabus 
yang dikoleksi merupakan spesies Channa striata dari Lampung Utara (Sumatera, SM), Lumajang (Jawa Timur, JW) dan Mandiangin (Kalimantan Selatan, KL). Populasi ikan gabus JW dan KL merupakan hasil budidaya yang telah terdomestikasi lebih dari 3 tahun, sedangkan populasi SM dikoleksi dari kolam pembesaran dengan benih tangkapan alam. Ketiga populasi tersebut telah diadaptasikan dengan pakan buatan.

\section{Penyediaan Hewan Uji}

Pemijahan alami sistem full-sib induk ikan gabus dilakukan dalam bak tembok ( $2 \mathrm{~m} \times 2 \mathrm{~m} \times 1 \mathrm{~m})$ dengan rasio kelamin 1 betina : 1 jantan. Betina matang gonad dan jantan agresif dari populasi SM, JW dan KL dipilih dan dipijahkan untuk menghasilkan benih uji. Telur yang diperoleh dari masing-masing bak pemijahan dikumpulkan menggunakan seser halus dan dipindahkan ke dalam bak inkubasi berisi $30 \mathrm{~L}$ air tawar yang telah diaerasi. Pemanas automatis diatur pada $29{ }^{\circ} \mathrm{C}$ dan ditempatkan dalam tangki inkubasi telur. Larva ikan gabus dipelihara selama 30 hari dalam wadah plastik dengan kepadatan awal 30 larva/L. Pada saat larva berumur dua hari diberi pakan alami tubifex selama 7 hari, dilanjutkan dengan pakan buatan yang mengandung $38 \%$ protein kasar hingga 30 hari pemeliharaan ikan.

Pemeliharaan ikan gabus lebih lanjut dilakukan untuk menghasilkan benih yang berukuran cukup besar untuk analisis kadar albumin dan evaluasi korelasi antara kadar albumin dengan karakter pertumbuhan (panjang total, panjang standar, bobot badan) dan kadar albumin darah. Benih ikan gabus dengan panjang total $28,9 \pm 5,7 \mathrm{~mm}$, dan bobot $0,27 \pm 0,09 \mathrm{~g}$ dari 12 famili, terdiri dari 4 famili untuk setiap populasi. Benih didistribusikan dalam 4 unit kolam tembok $(5 \mathrm{~m} \times 5 \mathrm{~m}$ $\times 0,5 \mathrm{~m}$ ) per populasi, dengan kepadatan tebar $1 \mathrm{ikan} /$ $\mathrm{m}^{2}$ (25 ikan/kolam) dan dipelihara selama 75 hari. Tepi kolam dipasang pagar untuk mencegah ikan melompat keluar dari kolam. Ikan diberi makan tiga kali sehari pada pukul 08.00, 12.00 dan 16.00 menggunakan pakan ikan terapung komersial (38\%protein kasar) sebanyak $5 \%$ dari biomassa. Pada akhir percobaan, dilakukan penimbangan bobot dan pengukuran panjang ikan.

\section{Analisis Albumin}

Kandungan albumin dianalisis sesuai dengan metode yang dikembangkan oleh Doumas et al. (1971). Kadar albumin diukur pada daging ikan gabus. Uji kadar albumin daging ikan gabus (ADG) dilakukan untuk menentukan koefisien keragaman dan untuk membandingkan tingkat albumin di antara tiga populasi ikan gabus. Untuk pengujian ADG, ikan gabus yang dipanen dimatikan dengan cara dimasukkan langsung ke dalam kotak berisi es $\left( \pm 4^{\circ} \mathrm{C}\right.$ ) selama 60 menit. Daging tanpa tulang diambil dari 20 ekor ikan uji untuk setiap populasi. Setiap sampel disimpan secara terpisah dalam kantong plastik kecil dan disimpan dalam suhu $-20^{\circ} \mathrm{C}$ hingga pengujian dilakukan. Bromocresol Green (BCG) dan larutan standar albumin (disiapkan dari Bovine Serum Albumin, BSA) digunakan sebagai reagen untuk analisis albumin. Pengujian kadar albumin dilakukan dengan mengukur absorbansi dalam sampel pada panjang gelombang 578 $\mathrm{nm}$. Sebanyak 2,5 ml pereaksi BCG 0,01\%ditambahkan ke dalam 0,5 ml ekstrak al bumin dan dibiarkan selama 10 - 15 menit. Sampel diukur nilai absorbansinya pada panjang gelombang $578 \mathrm{~nm}$.

\section{Kualitas Air}

Parameter kualitas air, meliputi suhu, pH dan konsentrasi oksigen terlarut (DO) diukur menggunakan alat pengukur kualitas air (WQC 22A TOA OK), sedangkan total ammonium nitrogen (TAN) dan nitrit diukur menggunakan spektrofotometer,mengacu pada APHA (1998).

\section{Analisis Data}

Data panjang dan bobot ikan uji disajikan sebagai rata-rata dan simpangan baku. Analisis statistik dilakukan dengan menggunakan program Exel 16. Korelasi kandungan albumin dengan parameter panjang total, panjang standar dan bobot badan dianalisis menggunakan uji Korelasi Spearman (Steel \& Torrie, 1999). Nilai keragaman dan korelasi pada populasi gabungan merupakan hasil analisis atas penggabungan data dari populasi Sumatera, Jawa dan Kalimantan. Koefisien keragaman (KK) dihitung berdasarkan formula sesuai Warwick et al., (1995):

$$
\mathrm{KK}=\frac{\mathrm{SD}}{\bar{X}} \times 100
$$

di mana: SD = standar deviasi

$$
X=\text { rataan populasi }
$$

\section{HASIL DAN BAHASAN}

\section{Keragaman kandungan albumin}

Kandungan albumin rata-rata ikan gabus populasi Sumatera (SM), Jawa (JW), Kalimantan (KL) dan Gabungan (GB) tidak menunjukkan perbedaan nyata (P>0.05), yaitu 2,6 $\pm 0,4 \mathrm{~g} \mathrm{dl}^{-1}(\mathrm{KL}) ; 2,4 \pm 0,3 \mathrm{~g} \mathrm{dl}^{-1}$ (SM) 2,2 $\pm 0,4 \mathrm{~g} \mathrm{dl}^{-1}(\mathrm{JV}) ;$ dan 2,4 $\pm 0,1 \mathrm{~g} \mathrm{dl}^{-1}(\mathrm{~GB})$; dengan koefisien keragaman (KK) yang relatif rendah, yaitu $12,60 \%(\mathrm{SM}), 18,13 \%(\mathrm{JT}), 17,0 \%(\mathrm{KL})$ dan $16,9 \%$ (GB). Data kandungan albumin dan koefisien keragaman ikan gabus dari keempat populasi disajikan pada Tabel 1. 
Tabel 1. Kandungan albumin dan koefisien keragaman ikan gabus (Chana striata) populasi Sumatera, Jawa, Kalimantan dan gabungan

Table 1. Albumin content and coefficient of variance of snakehead fish from Sumatra, Java, Kalimantan, and compositepopulations

\begin{tabular}{lcccc}
\hline \multirow{2}{*}{\multicolumn{1}{c}{ Parameter (Parameters) }} & \multicolumn{4}{c}{ Populasi (Population) } \\
\cline { 2 - 5 } & Sumatera & Jawa & Kalimantan & Gabungan \\
& Sumatra & Java & Kalimantan & Composite \\
\hline Panjang Total (Total length) (mm) & $138.3 \pm 29.3$ & $154.7 \pm 24.4$ & $127.2 \pm 24.8$ & $140.8 \pm 28.6$ \\
Panjang standar (Standard length) (mm) & $117.3 \pm 25.7$ & $130.3 \pm 24.0$ & $107.1 \pm 22.4$ & $119.0 \pm 24.9$ \\
Bobot badan (Body weight) (g) & $22.81 \pm 13.77$ & $28.6 \pm 12.82$ & $17.56 \pm 10.56$ & $23.4 \pm 13.35$ \\
Kadar albumin (Albumin content) (g dl-1) & $2.4 \pm 0.3$ & $2.2 \pm 0.4$ & $2.6 \pm 0.4$ & $2.4 \pm 0.1$ \\
Koefisien keragaman (Coefficient of variance) (\%) & 12.60 & 18.13 & $17.0 \%$ & $16.9 \%$ \\
\hline
\end{tabular}

Albumin merupakan komponen penting dari ikan gabus karena memiliki sejumlah manfaat bagi kesehatan manusia (Mustafa et al. 2012). Hasil yang diperoleh pada penelitian ini menunjukkan bahwa ikan gabus populasi Sumatera, Jawa dan Kalimantan yang dipelihara dengan ukuran, lingkungan, lama pemeliharaan dan pakan yang sama memiliki kandungan albumin yang relatif sama (tidak berbeda nyata). Dengan kata lain, perbedaan sumber populasi ikan gabus tidak berpengaruh nyata terhadap kandungan albumin. Sementara itu, sejumlah studi komparatif terhadap kandungan albumin ikan gabus telah dilakukan di Indonesia dan cenderung mengarah pada adanya perbedaan atau variasi kandungan albumin antar populasi. Dinyatakan oleh Susilowati et al. (2015) dan Chasanah et al. (2015) bahwa kandungan albumin C. striata dari Jawa Barat lebih tinggi $(107,28$ $\pm 3,19 \mathrm{mg} / \mathrm{g}$ ) dibandingkan albumin C. striata dari Jawa Timur $(91,1024,08 \mathrm{mg} / \mathrm{g})$ dan Jawa Tengah $(75,79 \pm$ 9,33 mg/g). Lebih lanjut, Fuadi et al. (2017) melaporkan bahwa kandungan albumin ikan gabus asal Kabupaten Lamongan (daerah air payau) secara signifikan lebih tinggi $(4,1 \pm 0,96 \mathrm{mg} / \mathrm{g})$ dibandingkan dengan kandungan albumin ikan gabus dari kabupaten Lumajang yang merupakan daerah air tawar $(2,9 \pm$ $0,87 \mathrm{mg} / \mathrm{g}$ ). Perbedaan hasil yang diperoleh pada penelitian ini dengan penelitian sebelumnya dikarenakan perbedaan sumber sampel yang digunakan. Penelitian sebelumnya membandingkan kandungan albumin ikan gabus yang dikoleksi dari lingkungan berbeda sehingga umur ikan, status fisiologis, jenis dan jumlah pakan, serta kondisi lingkungan tempat sumber sampel ikan uji diperoleh berbeda. Sementara itu, sampel yang dianalisis pada penelitian ini menggunakan ikan gabus yang dipelihara dengan umur, lingkungan pemeliharaan dan jenis pakan yang sama. Fuadi et al. (2017) menjelaskan bahwa kandungan albumin yang lebih tinggi pada ikan gabus yang diperoleh dari perairan payau dibandingkan ikan gabus yang diperoleh dari perairan tawar disebabkan oleh diversitas plankton dan ikan kecil di perairan payau lebih tinggi dibandingkan perairan tawar sehingga asupan protein yang diperoleh ikan gabus dari perairan payau juga lebih tinggi. Sejumlah faktor yang memengaruhi kandungan al bumin pada ikan gabus dinyatakan oleh Asikin \& Kusumaningrum (2018) dan Hariati et al. (2019), di antaranya spesies ikan, ukuran, tingkat konsumsi makanan, ketersediaan makanan dan tingkat kecernaan. Ditegaskan pula oleh Kovyrshina \& Rudneva (2012), bahwa status fisiologis, umur, musim, dan habitat berpengaruh nyata terhadap konsentrasi albumin pada ikan round goby (Neogobius melanostomus) dan ikan-ikan laut dari ordo Perciformes (Januar et al., 2015). Keberadaan senyawa polutan, seperti pestisida, dilaporkan menurunkan kandungan albumin pada ikan lele Afrika, Heterobranchus bidorsalis dikarenakan menyebabkan gangguan fisiologis ikan (Inyang et al., 2018).

Albumin merupakan protein utama (50\%dari total protein) dalam darah dan memiliki sejumlah peran penting dalam transport nutrien dan menjaga tekanan osmotik (Victoria et al., 2007), sehingga kadarnya akan dipertahankan dalam kondisi seimbang melalui sejumlah mekanisme (Rothschild et al., 1977). Dijelaskan secara detail oleh Bertholf (2014) bahwa kandungan albumin dipengaruhi oleh tiga proses, yaitu sintesis (anabolisme), penguraian (katabolisme) dan distribusi. Sintesis albumin secara dominan dipengaruhi oleh faktor nutrisi. Lebih spesifik, kecukupan asupan sumber $\mathrm{N}$ merupakan hal paling mendasar dalam sintesis albumin dan protein lainnya. Pemberian sejumlah asam amino, seperti triptofan, arginin, ornithine, lisin, fenilalanin, glutamin, alanin, treonin dan prolin akan meningkatkan sintesis albumin. Selain aspek nutrisi, beberapa faktor lain seperti tekanan osmotik, lingkungan, hormon (tiroid, kortison, insulin, hormon pertumbuhan) dan status 
fisiologis atau kesehatan ikan juga berpengaruh terhadap proses sintesis albumin. Sementara itu, mekanisme degradasi albumin belum banyak terungkap. Katabolisme albumin cenderung konstan, baik pada organisme tingkat tinggi maupun sejumlah spesies hewan berukuran kecil. Namun demikian, degradasi albumin cenderung berkurang ketika cadangan albumin di hati rendah. Hal tersebut sebagai upaya untuk mencegah semakin menurunnya kandungan albumin. Kelebihan kandungan hormon tiroid dan kortison akan memicu peningkatan degradasi albumin. Kortison meningkatkan distribusi nitrogen ke hati sehingga degradasi protein (termasuk albumin) di otot, jaringan penghubung dan jaringan limfatik juga meningkat. Dinyatakan lebih lanjut bahwa hormon kortison juga memengaruhi laju distribusi albumin dari hati ke plasma darah.

Di samping tidak berbeda antar sumber populasi, ternyata karakter kandungan albumin ikan gabus juga memiliki koefisien keragaman rendah (12-18\%, baik pada populasi Sumatera, Jawa, Kalimantan, atau populasi gabungan. Tampake et al. (1992) mengklasifikasikan keragaman suatu karakter ke dalam tiga kelompok, yaitu rendah dengan KK sebesar $0-20 \%$, sedang (20-50\%), dan tinggi (>50\%). Dikarenakan nilai KK karakter kandungan albumin tergolong rendah, maka seleksi individu berdasarkan karakter tersebut pada populasi ikan gabus Sumatera, Jawa dan Kalimantan kurang efektif untuk dilakukan. Nilai koefisien keragaman menunjukkan nilai keragaman dari karakter tersebut pada populasi yang diamati. Semakin tinggi nilai koefisien keragaman semakin heterogen populasi yang diukur, sehingga seleksi lebih memungkinkan dilakukan terhadap karakter tersebut (Falconer \& Mackay, 1996).

\section{Korelasi Karakter Pertumbuhan dan Kandungan Albumin}

Karakter kandungan albumin daging ikan gabus merupakan karakter kualitatif yang tidak dapat diketahui melalui pengamatan secara visual dan dalam proses analisisnya menyebabkan ikan berpotensi mati atau harus dibunuh, sehingga penggunaan detektor atau karakter lain sebagai penduga karakter tersebut sangat diperlukan. Pendekatan ini dilakukan dengan pertimbangan bahwa ikan dengan kandungan albumin tinggi akan digunakan sebagai kandidat induk untuk membentuk generasi berikutnya. Korelasi Pearson antara parameter panjang-bobot ikan terhadap kandungan albumin daging ikan gabus populasi Sumatera, Jawa, Kalimantan, dan populasi gabungannya tergolong rendah hingga sedang. Korelasi karakter panjang total dengan kandungan albumin sebesar $-0,28$ - 0,42\% (Gambar 1); panjang standar dengan kandungan albumin sebesar $-0,35-0,47 \%($ Gambar 2); dan bobot badan dengan kandungan albumin sebesar -0,275 0,3 \% (Gambar 3).

Hasil analisis korelasi Pearson karakter panjang total (PT), panjang standar (PS) dan bobot badan (BB) terhadap karakter kandungan albumin daging (ADG) ikan gabus populasi Sumatera dan Kalimantan sangat rendah dan sebagian lainnya cenderung negatif. Hal tersebut menunjukkan bahwa karakter-karakter tersebut tidak potensial digunakan sebagai penduga kandungan albumin daging pada populasi Sumatera dan Kalimantan. Pola korelasi negatif antara panjang badan dengan kandungan albumin ikan gabus juga dilaporkan oleh Gam et al. (2006) dan Alfarisy et al. (2013). Sementara itu, nilai korelasi karakter PT, PS dan BB terhadap ADG ikan gabus populasi Jawa bersifat positif dengan kategori sedang, secara berurutan sebesar 0,42; 0,475 dan 0,34 untuk karakter PT, PS dan BB. Pola korelasi panjang-bobot terhadap kadar albumin ikan gabus populasi Jawa berbeda dengan pola korelasi pada populasi Sumatera dan Kalimantan. Hal tersebut diduga karena populasi ikan gabus Jawa memiliki jarak genetik cukup jauh dengan populasi Sumatera dan Kalimantan (Gustiano et al., 2013). Secara umum semakin jauh jarak genetik diantara populasi populasi yang diamati, maka semakin sedikit kemiripan karakter antar populasi tersebut.

Perbaikan kualitas daging ikan melalui pendekatan seleksi telah dilakukan pada sejumlah ikan konsumsi komersial, termasuk Salmon (Rye, 1991; Wold et al., 2004); river catfish (Sang et al., 2009), rainbow (Folkestad et al., 2008) menggunakan metode seleksi tidak langsung (indirect selection), yang didasarkan pada nilai korelasi antara karakter yang lebih mudah diukur (prediktor) dengan karakter utama yang bersifat kualitatif. Folkestad et al. (2008) melaporkan bahwa keberhasilan seleksi ikan salmon pada karakter kandungan lemak dan kandungan karotenoid dilakukan dengan pendekatan nilai korelasi antara hasil analisis biokimia dengan nilai yang terukur pada spektroskop infrared, dengan nilai korelasi sebesar 0,95 dan 0,92. Dinyatakan pula oleh Gjedrem (2017) bahwa penggunaan karakter prediktor yang memiliki korelasi tinggi, rata-rata di atas 0,84 , terhadap karakter utama memberikan dampak nyata terhadap capaian seleksi yang dilakukan.

\section{Kualitas air}

Parameter-parameter kualitas air antar kolam pemeliharaan benih ikan gabus, meliputi suhu, konsentrasi oksigen terlarut, dissolved oxygen (DO), $\mathrm{pH}$, amonia $\left(\mathrm{NH}_{3}\right)$, nitrit $\left(\mathrm{NO}_{2}\right)$ selama penelitian relatif sama sehingga bukan menjadi penyebab perbedaan 

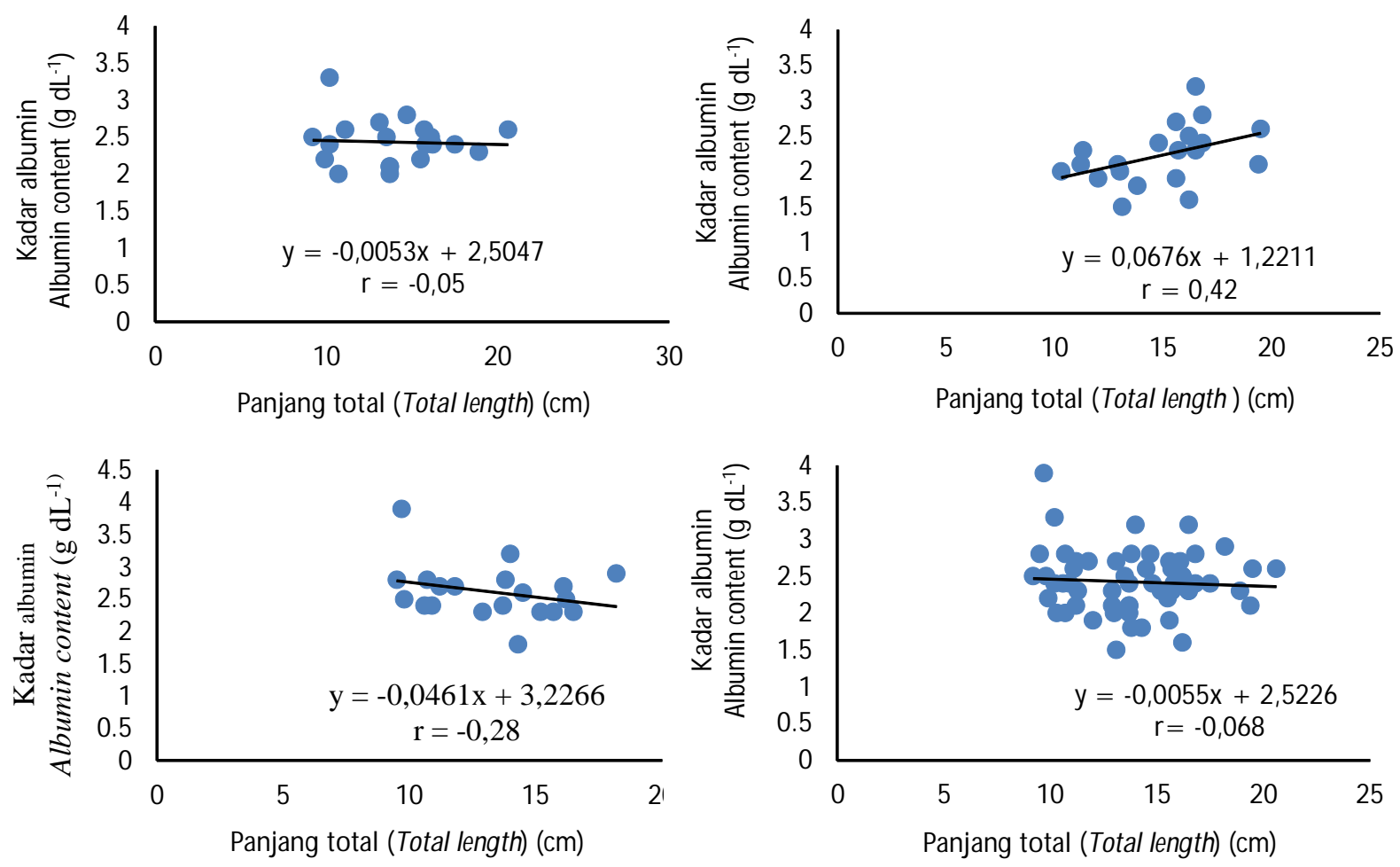

Gambar 1. Korelasi parameter panjang total terhadap kadar albumin ikan gabus (Chana striata) populasi Sumatera, Jawa, Kalimantan dan gabungan.

Figure 1. Correlation between total length and albumin content of snakehead fish of Sumatera, Java, Kalimantan and composite populations.
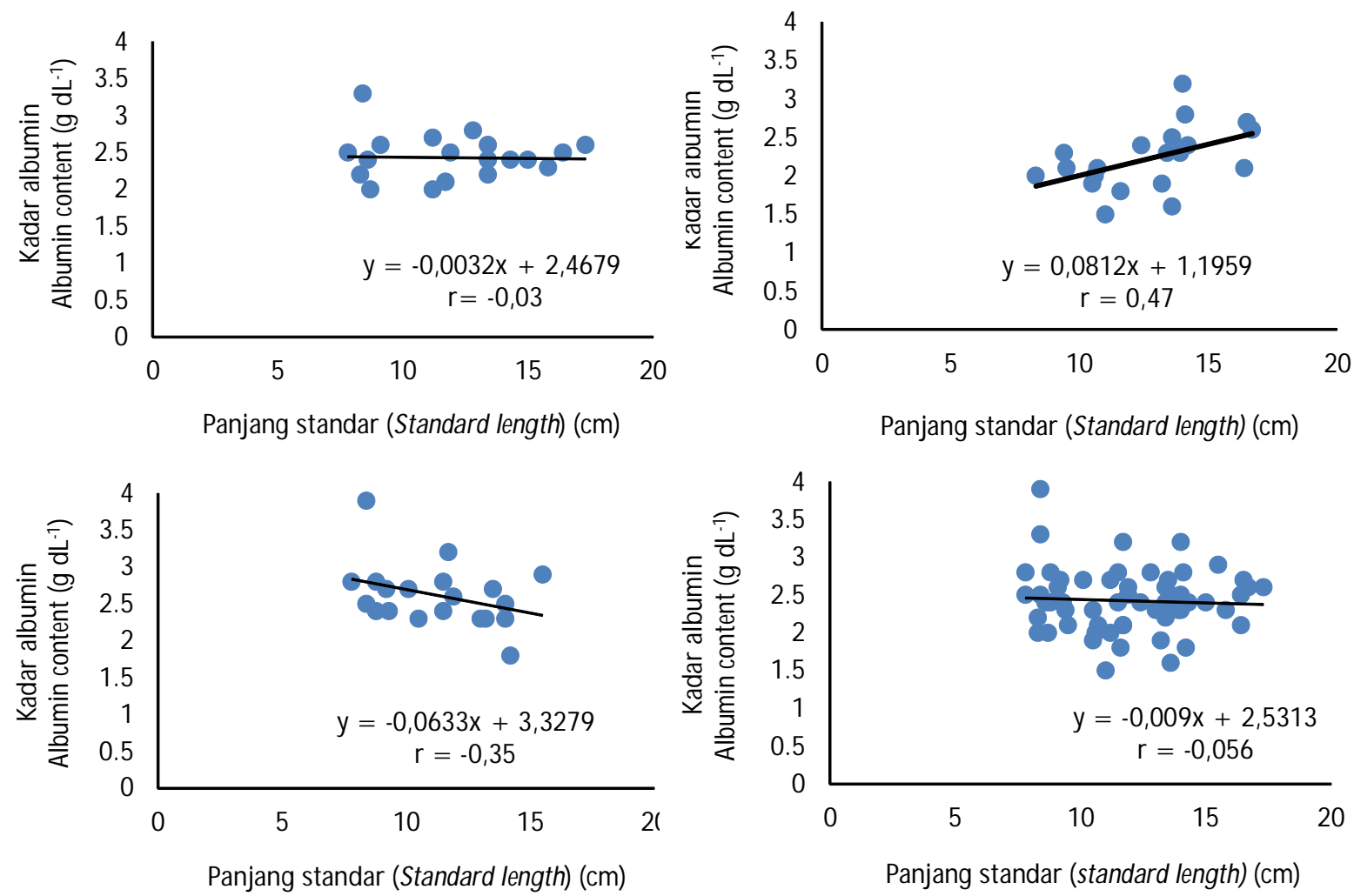

Gambar 2. Korelasi parameter panjang standar terhadap kadar albumin ikan gabus (Chana striata) populasi Sumatera, Jawa, Kalimantan dan gabungan.

Figure 2. Correlation between standard length and albumin content of snakehead fish of Sumatera, Java, Kalimantan and composite populations. 


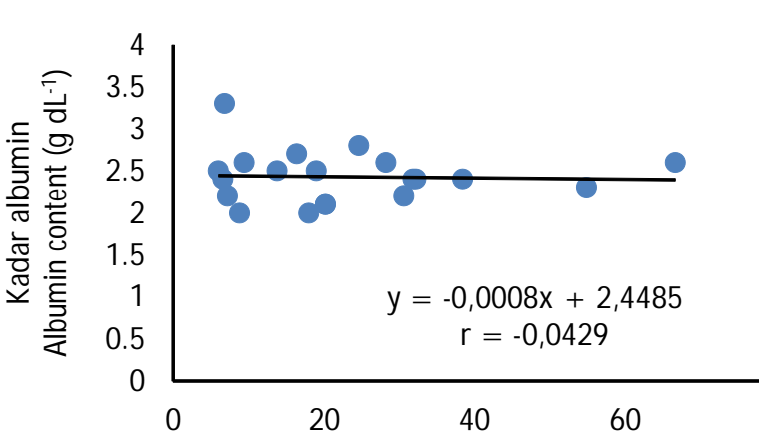

Bobot badan (body weight) (g)

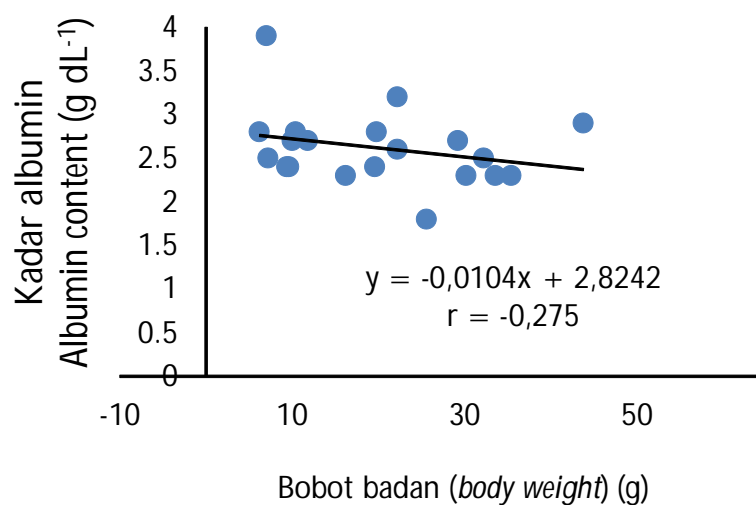

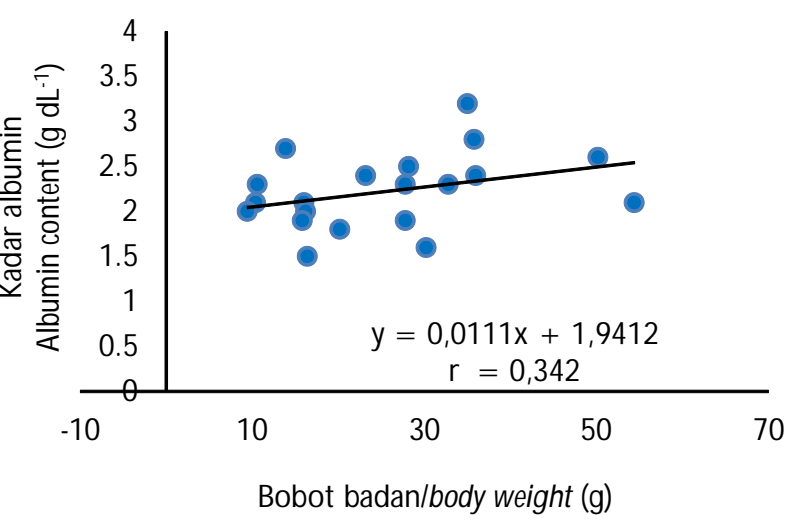

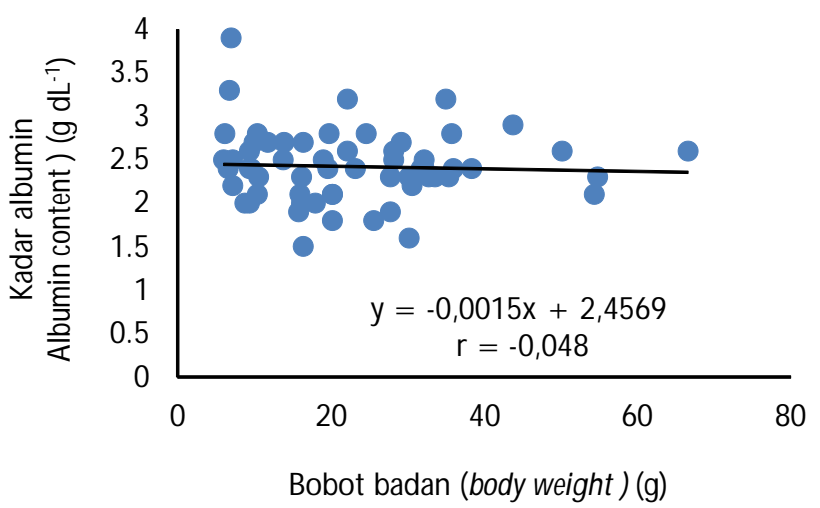

Gambar 3. Korelasi parameter bobot badan terhadap kadar albumin ikan gabus (Chana striata) populasi Sumatera, Jawa, Kalimantan dan gabungan.

Figure 3. Correlation between body weight and albumin content of snakehead fish of Sumatra, Java, Kalimantan and composite population.

kandungan albumin pada ketiga populasi ikan gabus yang dipelihara. Suhu air pada pagi hari relatif rendah hingga $25^{\circ} \mathrm{C}$, sedangkan pada tengah hari relatif tinggi hingga $34,6{ }^{\circ} \mathrm{C} ; \mathrm{pH}$ air pada tergolong optimal, dengan kisaran 7,3-8,4; kadar oksigen terlarut berfluktuasi, pada pagi hari $1,3 \mathrm{mg} / \mathrm{L}$ dan pada sore mencapai 6,8 $\mathrm{mg} / \mathrm{L} ;$ Kadar amonia sangat rendah $(0,01-0,03 \mathrm{mg} / \mathrm{L})$ dan demikian pula kadar nitrit $(0,01-0,1 \mathrm{mg} / \mathrm{L})$. Berdasarkan Boyd (1990), Qin et al. (1997) dan Courtenay \& Williams (2004), kualitas air yang sesuai untuk kehidupan ikan gabus adalah pada kisaran suhu $26-32{ }^{\circ} \mathrm{C}$; oksigen terlarut minimal $5 \mathrm{mg} / \mathrm{L} ; \mathrm{pH} \mathrm{4,25}$ - 9,4; kadar amonia 0,54 - 1,57 dan kadar nitrit kurang dari $0,1 \mathrm{mg} / \mathrm{L}$, sehingga sebagian besar parameter kualitas air dalam kisaran layak untuk kehidupan ikan gabus.

\section{KESIMPULAN}

Keragaman kadar albumin pada po pulasi ikan gabus Sumatera, Jawa dan Kalimantan tergolong rendah dan tidak berbeda nyata secara statistik $(P>0,05)$ sehingga peningkatan kandungan albumin dengan pendekatan seleksi kurang efektif. Nilai korelasi karakter pertumbuhan terhadap kadar albumin tergolong rendah hingga sedang dan bersifat spesifik populasi.

\section{UCAPAN TERIMA KASIH}

Penulis menyampaikan rasa terima kasih kepada Kepala Balai Riset Pemuliaan Ikan yang telah memberikan pendanaan dan fasilitas. Penghargaan dan terima kasih kepada para teknisi komoditas ikan gabus di Balai Riset Pemuliaan Ikan dan pihak-pihak yang terlibat selama koleksi data maupun dalam penyelesaian makalah ini.

\section{DAFTAR ACUAN}

Alfarisy, M.U., Abdulgani, N., \& Ulfin I. (2013). Pengaruh jenis kelamin dan ukuran terhadap kadar albumin pada ikan gabus (Channa striata). Jurnal Sains dan Seni Pomits, 2(1), 1-4.

Andreeva, A.M. (2010). Structure of Fish Serum Albumins. Journal of Evolutionary Biochemistry and Physiology, 46(2), 135-144.

Andreeva, A.M. (2011). Mechanisms of the plurality of Scorpaena porcus L. Serum Albumin. Open Journal of Marine Science, 1(2), 31-5. 
APHA. (1998). Standard methods for the examination of the water and wastewater (1268 pp). Washington, D.C.: American Public Health Association.

Asikin, A.N. \& Kusumaningrum, I. (2018). Characteristics of snakehead fish protein extract based on fish weight size from Mahakam, East Kalimantan.Jurnal Hasil Perikanan Indonesia, 21(1), 132-42.

Baker, M.E. (2002). Albumin, steroid hormones and the origin of vertebrates. Journal of Endocrinology 175, 121-127.

Bertholf, R.L. (2014). Proteins and albumin. Medicine, 45(1), 25-41.

Boyd, C.E. (1990). Water Quality in Ponds for Aquaculture. (359 p) Birmingham, Alabama: Auburn University Press.

Chasanah, E., Nurilmala, M., Purnamasari, A.R., \& Fithriani, D. (2015). Komposisi kimia, kandungan albumin and bioaktivitas ekstrak protein kasar pada ikan gabus, Channa striata alam dan hasil budidaya. Jurnal Pascapanen dan Bioteknologi Kelautan dan Perikanan, 10(2), 123-32.

Courtenay, Jr.W.R. \& Williams, J.D. (2004). Snakeheads (Pisces, Channidae) - A biological synopsis and risk assesment (143 pp). U.S. Geological Survey, Denver.

Doumas, B.T., Watson, W.A., \& Biggs, H.G. (1971). Albumin standards and the measurement of serum albumin with bromcresol green. International Journal of Clinical Chemistry, 31(1), 87-96.

Dwijayanti, D.R., Djati, M.S., \& Rifa'i, M. (2016). The role of vipalbumin as an immunostimulatory agent for controlling homeostasis and proliferation of Iymphoid cells. Central European Journal of Immunology, 41(1), 31-38.

Falconer, D.S. \& Mackay, T.F.C. (1996). Introduction to quantitative genetics, 4th edition. Essex, UK.

Folkestad, A., Wold, J.P., Rørvik, K.J., Tschudi, J., Haugholt, K.H., Kolstad, K., \& Mørkøre, T. (2008). Rapid and non-invasive measurments of fat and pigment concentrations in live and slaughtered Atlantic salmon (Salmo salar L). Aquaculture, 280, 129-135.

Fuadi, M., Santoso, H., \& Syauqi, A. (2017). Uji kandungan albumin ikan gabus (Channa striata) dalam Perbedaan Lingkungan Air. Bioscience-Tropic, 3(1), 23-30.

Gam, L.H., Leow, C.Y., \& Baie, B. (2006). Proteomic Analysis of Snakehead Fish (Channa striata) Muscle Tissue. Malaysian Journal of Biochemistry and Molecular Biology, 14, 25-32.
Gjedrem, T. (1983). Genetic variation in quantitative traits and selective breeding in fish and shellfish. Aquaculture, 33, 51-72.

Gjedrem, T. \& Baranski, M. (2009). Selective Breeding in Aquacultute; an Introduction (221 p). London (GB): Springer.

Gjedrem, T. (2012). Genetic improvement for the development of efûcient global aquaculture: a personal opinion review. Aquaculture, 344, 12-22.

Gjedrem, T., Robinson, N., \& Rye, M. (2012). The important of selective breeding in aquaculture to meet future demands for animal protein: A review. Aquaculture, 350-353, 117-129.

Gjedrem, T. (2017). Possibility for improving carcass composition and meat quality traits by selective breeding. Int J Cur Res Rev, 9(10), 11-18.

Gustiano, R., Oktaviani, T., So elistyowati, D.T., Kusmini, I.I., Wahyutomo, \& Humoyono, G.H. (2013). Analisis ragam genotip RAPD dan fenotip truss morfometrik pada tiga populasi ikan gabus [(Chana striata (Bloch, 1793)]. Berita Biologi, 12(3), 325-333.

Gustiano, R., Ath-thar, M.H.F., \& Kusmini, I.I. (2019). Diversiti, biologi reproduksi dan manajemen induk ikan gabus. IPB Press., $104+$ xiv.

Hariati, A.M., Endariani, A.Y., Kusuma W.E., \& Wiadnya, D.G.R. (2019). Albumin and enzyme profiles of dwarf snakehead, Channa gachua caught from River Brantas, East Java. Journal of Physics: Conference Series, 1146, 1-5.

Inyang, I.R., Izah, S.C., \& Ntaka, C.M. (2018). Effect of imidacloprid on total protein, albumin and electrolytes in Heterobranchus bidorsalis. Environment Analysis and Ecology study, 4(5), 424-427. DOI: 10.31031/EAES.2018.04. 000597.

Januar, H.I., Fajarningsih, N.D., Zilda, D.S., Bramandito, A., \& Wright, A.D. (2015). Concentration of fish serum albumin (FSA) in the aqueous extract of Indonesian Perciformes fishes' muscle tissue, Natural Product Research, p. 1-3. DOI: 10.1080/ 14786419.2014.1003298.

Kovyrshina, T.B. \& Rudneva, I.I. (2012). Comparative study of serum albumin level in round goby Neogobius melanostomus form Black Sea and Azov Sea. International Journal of Advanced Biological Research, 2, 203-208.

Mustafa, A., Widodo, M.A., \& Kristianto, Y. (2012). Albumin and zinc content of snakehead fish (Channa striata) extract and its role in health. International Journal of Science and Technology, 1(2), 1-8. 
Qin, J.G, Fast, A.W., \& Kai, A.T. (1997). Tolerance of snakehead Channa striatus to ammonia at different $\mathrm{pH}$. Journal of the World Aquaculture Society, 28, 87-90.

Rahman, M.A., Molla, M.H.R., Sarker, M.K., Chowdhury, S.H. \& Shaikh, M.M. (2018). Snakehead fish (Channa striata) and its biochemical properties for therapeutics and health benefits. Journal of Biotechnology Biomedic Engineering, $1(1), 1-5$.

Rodríguez, F.H., Cáceres, G., Lhorente, J.P., Newman, S., Bangera, R., Neira, R., \& Yáñez, J.M. (2018). Genetic (co)variation in skin pigmentation patterns and growth in rainbow trout. Animal, p. 1- 8.

Rothschild, M.A., Murray, O., \& Schreiber, S.S. (1977). Albumin synthesis. The Radioisotope Service, New York, 246 pp.

Rye, M. (1991). Prediction of carcass composition in Atlantic salmon by computerized tomography. Aquaculture, 99(1), 35-48.

Sang, N., Thomassen, M., Klemetsdal, H. \& Gjøen, H.M. (2009). Prediction of fillet weight, fillet yield, and fillet fat for live river Catfish (Pangasianodon hypophthalmus). Aquaculture, 288, 166-171.

Siswanto, A., Dewi, N., \& Hayatie, L. (2016). Effect of haruan (Channa striata) extract on fibroblast cells count in wound healing. Journal of Dentomaxillofacial Science, 1(2), 89-94.

Steel, R.G.D \& Torrie, J.H. (1999). Principles and Procedure of Statistic. (666 p) McGrawHill, London.
Susilowati, R., Januar, H.I., Fithriani, D., \& Chasanah, E. (2015). Potensi ikan budidaya air tawar sebagai bahan dasar untuk produk-produk netriseutikal berbahan dasar albumin serum ikan. Jurnal Pascapanen dan Bioteknologi Kelautan dan Perikanan, 10(1), 37-44.

Suwandi, R., Nurjanah, \& Winem, M. (2014). Proporsi bagian tubuh dan kadar proksimat ikan gabus pada berbagai ukuran. Jurnal Pengolahan Hasil Perikanan Indonesia, 17(1), 22-28.

Tampake, Pramono, H.D., \& Luntungan, H.T. (1992). Keragaman fenotipik sifat-sifat generatif dan komponen buah beberapa jenis kelapa di lahan gambut pasang surut, Sumatera Selatan. Buletin Balitka, 18, 16-21.

Victoria, J.M., Peter, M.G., \& Stephen O.B. (2007). Lungfish albumin is more similar to tetrapod than to teleost albumins: Purification and characterisation of albumin from the Australian lungfish, Neoceratodus forsteri. Comparative Biochemistry and Physiology, 147, 428-437.

Warwick, E.J., Astuti, J.M., \& Hardjosubroto, W. (1995). Pemuliaan Ternak. (485 p) Gadjah Mada University Press. Yogyakarta.

Wold, J.P., Marquardt, B.K., Dable, B.K., Robb, D., \& Halen, B. (2004). Rapid quantification of carotenoids and fat in Atlantic salmon (Salmo salar L.) by raman spectroscopy and chemometrics. Applied Spectroscopy, 58, 395-403.

Zhang, Y.X., Lai, R., Lee, W.H., \& Zhang, Y. (2005). Frog albumin is expressed in skin and characterized as a novel potent trypsin inhibitor. Protein Science, 14, 2469-2477. 